\title{
EFFECT OF Cola pachycarpa AND Cola lepidota FRUIT JUICES ON LIVER FUNCTION PARAMETERS AND HISTOPATHOLOGICAL INDICES OF ALLOXAN INDUCED ADULT MALE DIABETIC WISTAR RATS
}

\author{
*Ngoka I.R., Chikwendu J.U. and Maduforo A.N. \\ Department of Nutrition and Dietetics, Faculty of Agriculture, University of Nigeria Nsukka, Enugu State, \\ Nigeria.
}

*Corresponding author's email address: rosengoka1@gmail.com

\begin{abstract}
Background: Diversity is a potential source for immense untapped material wealth in the forms of food, medicine and other amenities. One of these neglected plants is Monkey Cola.

Objective: The study evaluated the effect of Cola pachycarpa and Cola lepidota fruit juices on the liver function parameters (aspartate transaminase, alanine transaminase, alkaline phosphatase \& total protein) and histopathological indices (liver tissue) of alloxan- induced diabetic rats.

Materials and methods: Fresh Cola pachycarpa and Cola lepidota fruits were obtained from local markets and home farms within communities in Isiala Mbano local government area of Imo State and Isiala Ngwa South local government area of Abia State. The fruits were processed into raw and undiluted fruit juice using an electric juicer. Forty healthy adult albino male rats with an average weight of $239.35 \mathrm{~g}$ were randomized into eight groups, six experimental and two control groups, based on body weight. All the rats in each group were induced with alloxan to become diabetic. Samples of blood were collected for use as basal biochemical and hematological indices as well as after induction with diabetes. Standard diabetic drug, glibenclamide and Cola fruit juices (pachycarpa and lepidota) were administered differently and in varied concentrations $(5 \mathrm{ml} / \mathrm{kg}$ and $10 \mathrm{ml} / \mathrm{kg}$ body weight). The experiment lasted for 21 days after which the animals were sedated with mild anesthetic and sacrificed by cervical dislocation. The liver of the animals were excised, packaged, labeled and stored for subsequent chemical analysis and histopathology. Data was analyzed statistically using IBM-SPSS (Special Package for Social Sciences) version 20 software for means and standard deviation.

Results: Monkey Cola fruit juices significantly $(\mathrm{p}<0.05)$ decreased alkaline phosphatase $(28.95 \%$, CPV1, Group that received Cola pachycarpa very rough epicarp fruit juice at $5 \mathrm{ml} / \mathrm{kg}$ body weight), aspartate transaminase (29.81\%, CPV1) comparative to those of the standard diabetic drug (29.58\% and $17.58 \%$ respectively). Histopathological studies indicated abnormal hepatocyte structure in only the untreated group of rats. Rats that received standard diabetic drug reported significant $(\mathrm{p}<0.05)$ better liver architecture from other treatment groups, though damage to the liver was not noticed in rats that received the fruit juices. All the Cola juices especially those administered at $10 \mathrm{mls} / \mathrm{kg}$ body weight impacted positively in improving body weight, haematological, biochemical and histopathological indices in diabetes control.
\end{abstract}

Conclusion: Further research could be done to establish its prospect as an anti-diabetic agent.

Keywords: Cola pachycarpa, Cola lepidota, fruit juices, haematological, histopathology, alloxan-induced, diabetic rats.

\section{INTRODUCTION}

Diabetes is one of the most frequently occurring non-infectious diseases which affect over 171 million humans worldwide. There is also a projection that those who will be affected with this disease may become twice this number by the year 2025 (1). Some researchers have described diabetes as a disease of great significance because of its harmful effect on the physical and emotional wellbeing of the affected (2). The treatment of diabetes mellitus cannot be handled with drugs alone since the disease has no cure (3). Diabetes mellitus (DM) is an increasing global health problem (4), therefore, frantic efforts are being made to search for new combinations and therapies to deal with this disease condition (5).

Fruits and vegetables can work together to exhibit antioxidant properties which will help reduce the incidence of extremely serious ill health especially cancers and cardiovascular diseases and other noncommunicable diseases like diabetes (6-8). This is the reason experts encourage the consumption of different kind of vegetables and fruits more than focusing on certain kinds. This method of fruit and vegetable consumption will ensure the intake of various important phytochemicals that are abundant in the ecosystem (9). Unprocessed fruits/vegetables and their juices when compared with the fried and boiled vegetables/fruits give much more nutrition and vitality. Thus, some of the eminent experts of modern medicine now lay emphasis on diet therapy and use of vegetables and fruit juices to assist the cure of diseases that cannot be cured by modern medicine and various other therapies (10).

According to Soetan, (11) researchers are devoting efforts towards tapping the medical and 
pharmacologic benefits of these foods and at the same time trying to keep the levels of anti-nutrients in these foods at minimal levels. Several researches have indicated positive potentials of various plant parts like their stem, barks, roots, fruits and the leaves to treat different diseases when applied whole or as extracts from these plant parts (12-14). This is to help solve the problem of drug resistance which is often encountered during the treatment of diseases. The medicinal ingredients naturally occurring in Monkey cola fruits can be obtained in form of juices, infusions, decoctions, essential oils, ointments and creams and used to treat and manage various disease conditions $(5,15)$.

Monkey Cola is a wild fruit with yellow, white and red varieties which is used by locals for nutritional and medicinal purposes. Much research efforts have not been extended to this plant. This is the motivation of interest in this virgin area of research. The present study focused on the effects of Cola pachycarpa and Cola lepidota fruit juices on the liver function markers (aspartate transaminase (AST), alanine transaminase (ALT), alkaline phosphatase (ALP), total protein and histopathological indices of alloxan-induced diabetic rats.

\section{MATERIALS AND METHODS \\ Study Design and Assays \\ The study design was experimental \\ Sample Collection and Preparation}

Three distinct varieties of Cola fruits were obtained from the local markets and home farms within the communities in Isiala Mbano Local Government Area of Imo State and Isiala Ngwa South L.G.A, Abia State, Nigeria; Cola pachycarpa, yellow mesocarp variety (smoother epicarp), yellow mesocarp variety (with very rough protrusions on epicarp) as well as Cola lepidota, a white mesocarp variety. The colour of the epicarps of these fruits ranged from light brown to deep brown. The epicarp was removed from the fruits obtained and the seed separated from the fruit. The mesocarp was washed with clean running tap water, chopped into bits and its raw juice extracted without addition of water using an electric juicer (Andrew James Power Juicer, PI-NO: HK8426 Model NO: QF-0614YB). This juice was packaged in small bottles and stored in the freezer until needed.

\section{Animal Procurement, Housing and Laboratory Analysis}

A total of forty healthy adult albino male rats (Wister strain) weighing between $150-345 \mathrm{~g}$ were used for this study. The rats were obtained from the animal house of the Department of Veterinary Medicine, University of Nigeria Nsukka and housed in single iron metabolic cages, under standard temperature and humidity in the Department of
Home Sciences, Nutrition and Dietetics, University of Nigeria, Nsukka and fed commercial pellet diet (rat chow) purchased from the Vital Feed shop in Nsukka, Enugu state. The rats were allotted randomly to eight groups of five rats each, based on body weight. The differences in the weight of rats in each group did not exceed $5 \mathrm{~g}$.

The animals were fasted for 12 hours and blood samples were collected and used to determine baseline biochemical and haematological values using accu-check glucometer (GU012687221, Roche, Mannheim, Germany) and its test strips. Then alloxan monohydrate powder was dissolved in normal saline and administered peritoneally (150mglkg body weight) to the fasted adult albino male rats. Forty-eight (48) hours after inducing the animals with diabetes, the level of blood glucose of the rats was measured using accu- check glucometer (GU012687221, Roche, Mannheim, Germany) and its test strips. Rats that recorded up to $200 \mathrm{mgldl}$ and above were considered diabetic (16). Their blood glucose levels were collected as well as blood samples for biochemical and haematological assay. Diabetic rats were grouped and treated with the Cola lepidota and Cola pachycarpa fruit juices.

The animals were separated into eight groups with five rats in each group making up 6 experimental groups with two control groups. The experimental animals were treated as follows: Group CPR1 received Cola pachycarpa (rough epicarp) fruit juice, $5 \mathrm{ml} / \mathrm{kg}$ body weight. Group CPR2 received Cola pachycarpa (rough epicarp) fruit juice, $10 \mathrm{ml} / \mathrm{kg}$ body weight. Group CPV1 received Cola pachycarpa (very rough epicarp) fruit juice, $5 \mathrm{ml} / \mathrm{kg}$ body weight. Group CPV2 received Cola pachycarpa (very rough epicarp) fruit juice, $10 \mathrm{ml} / \mathrm{kg}$ body weight. Group CL1 received Cola lepidota fruit juice, $5 \mathrm{ml} / \mathrm{kg}$ body weight. Group CL2 received Cola lepidota, $10 \mathrm{ml} / \mathrm{kg}$ body weight. Group TSD was the positive control group, received $5 \mathrm{mg} / \mathrm{kg}$ body weight glibenclamide, standard diabetic drug. Group NT was the negative control, which was induced without treatment. At the end of the 21-day experimental period, the animals were weighed and sacrificed. The blood was collected for biochemical and haematological analysis while their liver was excised and preserved for histological studies (17). The supernatant was separated to get the serum which was stored in bijou bottles for biochemical and haematological analysis.

\section{Liver Function Test Activity}

Aspartate aminotransferase activity was determined with the method of Reitman and Frankel (18). Alanine aminotransferase activity was determined by the method of Reitman and Frankel (18). The method of Babson et al. (19) was used in the assay 
of alkaline phosphatase activity. Total protein content was measured by the method of Tietz, (20).

\section{Statistical Analysis}

Data obtained was analysed using IBM-SPSS (Special Package for Social Sciences, IBM-SPSS Statistics data editor), version 20 for means and standard deviation. Results of replicate experiments were expressed as means \pm SEM. Data generated from questionnaire was analyzed using frequencies and percentages. Analysis of variance (ANOVA) was used to compare means and Post- hoc analysis was conducted to separate significant difference between control and experimental groups at $95 \%$ confidence level using Duncan's New Multiple Range Test. $\mathrm{P}$ values $<0.05$ were considered to be significant.

\section{RESULTS}

Effects of Cola pachycarpa \& Cola lepidota fruit juices on the biochemical indices of induced diabetic rats.

Alkaline phosphatase (iu/L)

The ALP results obtained among groups after acclamatization varied significantly $(\mathrm{p}<0.05)$. After induction with diabetes, ALP values increased in all groups of rats, being statistically similar $(p<0.05)$, Table 1. With treatment, ALP values showed gradual significant $(\mathrm{p}<0.05)$ decrease in all treatment groups (those being treated with Cola pachycarpa and Cola lepidota fruit juices and diabetic drug, TSD). Levels of ALP in the blood increased by $+6.79 \%$ in the untreated group, NT while the group treated with standard drug, TSD recorded the highest decrease in ALP value ($29.58 \%$ ).

Alanine Transaminase, ALT (iu/L)

Table 1 shows the effects of treatment groups on ALT of the rats. Group CL1 showed the highest significant $(\mathrm{p}<0.05)$ value of ALT in baseline while group NT recorded the least $(42.60 \pm 1.03)$. However, group NT recorded the highest $(\mathrm{p}<0.05)$ results of ALT on treatment, with a $+16.90 \%$ increase in ALT. All the rats treated with cola juices and standard drug had percentage reductions in ALT values without any significant $(\mathrm{p}>0.05)$ difference, though group CL1 had the greatest value $(-32.26 \%)$.

\section{Aspartate Transaminase, AST (iu/L)}

Different $(\mathrm{p}<0.05)$ levels of AST values were recorded before induction among groups, with groups CL2 and NT showing the highest and the least values of AST respectively. On induction with diabetes all groups showed significant $(\mathrm{p}<0.05)$ elevated AST levels, group CL2 still maintaining the highest significant $(\mathrm{p}<0.05)$ level of AST. End values indicated lower AST in all treatment groups except for NT (infected, not treated) which suffered a $+14.79 \%$ increase in AST level. Some of the rats treated with Cola pachycarpa juices showed statistically similar percentage reduction in AST with those treated with standard drug, TSD ($10.93 \%,-29.81 \%, \&-17.58 \%$ respectively), Table 1 . Only group TSD recorded a significant $(\mathrm{p}<0.05)$ progressive decrease in AST throughout the treatment period.

\section{Total protein (TP) (mg/dl)}

Protein values decreased on induction with very similar $(p>0.05)$ values recorded among groups. Upon commencement of treatment, TP values increased with groups CPR1 and CPR2 recording the highest significant $(p<0.05)$ values of TP. End values indicated TP results being lowest for the untreated group, NT with a $-44.83 \%$ decrease in serum protein indicating severe infection. The group treated with standard drug recorded the lowest increase in total protein $(+2.66 \%)$, while the rats treated with Cola pachycarpa and Cola lepidota fruit juices at different doses had the highest TP increases ranging from $+42.86 \%$ to $+115.04 \%$. 
Journal of Dietitians Association of Nigeria (JDAN) Volume 12. December, 2021 Print ISSN: 2141-8209; eISSN: 2635-3326 Available online at: $w$ ww.jdan.org.ng; https://www.ajol.info/index.php/jdan/index

DOI: $\underline{\text { https://dx.doi.org/10.4314/jdan.v12i1.13 }}$

Table 1. Effect of Cola pachycarpa and Cola lepidota fruit juices on alkaline phosphatase, aspartate transaminase, alanine transaminase and total protein of induced diabetic rats.

\begin{tabular}{|c|c|c|c|}
\hline Treatment Group & Before Treatment & After Treatment & \% Change \\
\hline \multicolumn{4}{|c|}{ Alkaline phosphatase (iu/L) } \\
\hline CPR1 & $74.00 \pm 2.68^{\mathrm{a}}$ & $63.40 \pm 1.54^{\mathrm{b}}$ & -14.32 \\
\hline CPR2 & $76.80 \pm 3.42^{\mathrm{a}}$ & $61.00 \pm 1.14^{\mathrm{b}}$ & -20.57 \\
\hline CPV1 & $76.00 \pm 2.02^{\mathrm{a}}$ & $54.00 \pm 1.58^{\mathrm{a}}$ & -28.95 \\
\hline CPV2 & $80.40 \pm 2.56^{\mathrm{a}}$ & $59.80 \pm 2.56^{\mathrm{b}}$ & -25.62 \\
\hline CL1 & $82.60 \pm 1.08^{\mathrm{a}}$ & $63.20 \pm 1.39^{\mathrm{b}}$ & -23.49 \\
\hline CL2 & $81.00 \pm 3.29^{\mathrm{a}}$ & $62.00 \pm 1.52^{\mathrm{b}}$ & -23.46 \\
\hline TSD & $76.40 \pm 2.11^{\mathrm{a}}$ & $53.80 \pm 2.06^{\mathrm{a}}$ & -29.58 \\
\hline NT & $76.60 \pm 3.37^{\mathrm{a}}$ & $81.80 \pm 2.45^{\mathrm{c}}$ & +6.79 \\
\hline \multicolumn{4}{|c|}{ Alanine transaminase (iu/L) } \\
\hline CPR1 & $53.40 \pm 2.11^{\mathrm{b}}$ & $41.20 \pm 1.36^{\mathrm{a}}$ & -22.85 \\
\hline CPR2 & $53.60 \pm 1.63^{\mathrm{b}}$ & $41.20 \pm 1.39^{\mathrm{a}}$ & -23.13 \\
\hline CPV1 & $52.40 \pm 3.47^{\mathrm{b}}$ & $44.40 \pm 2.99^{\mathrm{ab}}$ & -15.27 \\
\hline CPV2 & $53.00 \pm 1.73^{\mathrm{b}}$ & $41.40 \pm 0.51^{\mathrm{a}}$ & -21.89 \\
\hline CL1 & $62.00 \pm 0.43^{c}$ & $42.00 \pm 1.58^{\mathrm{a}}$ & -32.26 \\
\hline CL2 & $50.80 \pm 2.78^{\mathrm{b}}$ & $40.80 \pm 1.83^{\mathrm{a}}$ & -19.69 \\
\hline TSD & $47.20 \pm 1.93^{\mathrm{ab}}$ & $41.60 \pm 1.17^{\mathrm{a}}$ & -11.86 \\
\hline NT & $42.60 \pm 1.03^{\mathrm{a}}$ & $49.80 \pm 2.83^{b}$ & +16.90 \\
\hline \multicolumn{4}{|c|}{ Aspartate transaminase (iu/L) } \\
\hline CPR1 & $36.60 \pm 1.08^{\mathrm{abc}}$ & $32.60 \pm 1.54^{\mathrm{abc}}$ & -10.93 \\
\hline CPR2 & $34.80 \pm 3.21^{\mathrm{ab}}$ & $33.00 \pm 2.19^{\mathrm{abc}}$ & -5.17 \\
\hline CPV1 & $41.60 \pm 1.47^{\mathrm{cd}}$ & $29.20 \pm 2.60^{\mathrm{ab}}$ & -29.81 \\
\hline CPV2 & $39.60 \pm 1.12^{\mathrm{bcd}}$ & $40.60 \pm 4.60^{c}$ & -2.53 \\
\hline CL1 & $39.80 \pm 0.66^{\mathrm{bcd}}$ & $35.80 \pm 1.56^{\mathrm{bc}}$ & -10.05 \\
\hline CL2 & $42.20 \pm 1.02^{\mathrm{d}}$ & $40.20 \pm 2.71^{\mathrm{c}}$ & -4.74 \\
\hline TSD & $33.00 \pm 1.41^{\mathrm{a} 3}$ & $27.20 \pm 0.97^{\mathrm{a} 2}$ & -17.58 \\
\hline NT & $33.80 \pm 1.74^{\mathrm{a}}$ & $38.80 \pm 1.84^{\mathrm{c}}$ & +14.79 \\
\hline \multicolumn{4}{|c|}{ Total Protein (mg/dl) } \\
\hline CPR1 & $2.83 \pm 0.22^{\mathrm{al}}$ & $5.30 \pm 0.09^{\mathrm{e} 3}$ & +87.94 \\
\hline CPR2 & $2.56 \pm 0.16^{\mathrm{al}}$ & $5.18 \pm 0.18^{\mathrm{de} 3}$ & +102.34 \\
\hline CPV1 & $2.26 \pm 0.40^{\mathrm{al}}$ & $4.86 \pm 0.20^{\text {cde } 3}$ & +115.04 \\
\hline CPV2 & $2.46 \pm 0.11^{\mathrm{al}}$ & $4.60 \pm 0.25^{\mathrm{de} 23}$ & +86.99 \\
\hline CL1 & $2.84 \pm 0.34^{\mathrm{al}}$ & $4.54 \pm 0.16^{\mathrm{d} 2}$ & +59.86 \\
\hline CL2 & $3.08 \pm 0.26^{\mathrm{a} 1}$ & $4.40 \pm 0.13^{\mathrm{c} 2}$ & +42.86 \\
\hline TSD & $3.00 \pm 0.29^{\mathrm{a} 1}$ & $3.08 \pm 0.23^{\mathrm{b} 1}$ & +2.66 \\
\hline NT & $2.90 \pm 0.29^{\mathrm{a} 2}$ & $1.60 \pm 0.25^{\mathrm{a} 1}$ & -44.83 \\
\hline
\end{tabular}

Means \pm SEM values with different alphabets as superscripts in a column differ significantly $(p<0.05)$.

Means \pm SEM values with different numbers as superscripts in a row differ significantly $(p<0.05)$.

Key

Group CPRI = received Cola pachycarpa (rough epicarp) fruit juice, $5 \mathrm{ml} / \mathrm{kg}$ body weight .

Group $C P R 2$ = received Cola pachycarpa (rough epicarp) fruit juice, $10 \mathrm{ml} / \mathrm{kg}$ body weight .

Group $C P V 1=$ received Cola pachycarpa (very rough epicarp) fruit juice, $5 \mathrm{ml} / \mathrm{kg}$ body weight.

Group CPV2 = received Cola pachycarpa (very rough epicarp) fruit juice, $10 \mathrm{ml} / \mathrm{kg}$ body weight.

Group CLI = received Cola lepidota fruit juice, $5 \mathrm{ml} / \mathrm{kg}$ body weight.

Group CL2 = received Cola lepidota, $10 \mathrm{ml} / \mathrm{kg}$ body weight.

Group TSD = was the positive control group, received $5 \mathrm{mg} / \mathrm{kg}$ body weight glibenclamide, standard diabetic drug.

Group NT = was the negative control, which was induced without treatment. 


\section{Histopathology of induced diabetic rats}

PLATES 11, 12, 13, 14, 15,16, 17 and 18 show the results of the histological examination of liver specimens from all groups of rats. The histological results indicated that the rats which received treatment with diabetic drug (TSD), glibenclamide exhibited a normal architecture of the liver, notably different from all the groups treated with monkey cola fruit juices (Cola pachycarpa and Cola lepidota) at different dosages. Results from rats treated with the fruit juices all suggested an apparent normal architecture of the liver. The untreated group (NT) however presented an abnormal architecture of hepatocytes, entirely different from all the other groups.

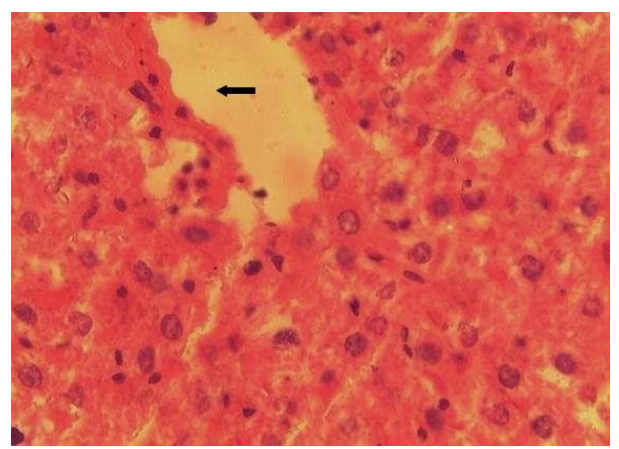

Plate 11: Group CPR1 diabetic rats fed with $5 \mathrm{mls}$ Cola pachycarpa rough epicarp variety juice per kg body weight. A Photomicrograph of sections of the liver from experimental rats in group CPR1, have degeneration and necrosis of hepatocytes that shows (arrow) peripotal and veinous/sinusoidal congestion ( $\mathrm{H}$ and $\mathrm{E} \mathrm{x} \mathrm{400).}$

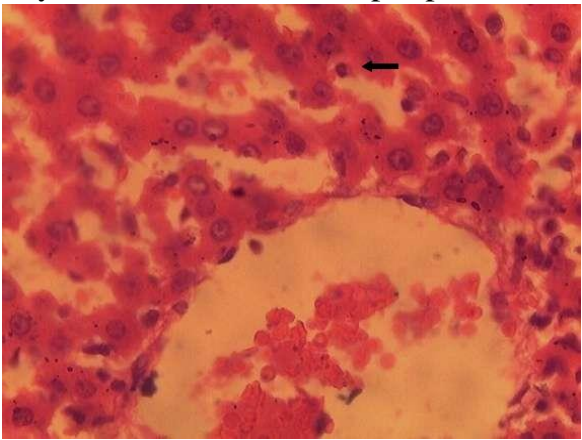

Plate 12: Group CPR2 diabetic rats fed with 10mls Cola pachycarpa rough epicarp variety juice per kg body weight. A liver section from the group CPR2 showing apparently normal hepatocytes distributed in a radial pattern away from the central veins with no significant change except mild congestion of the central veins ( $\mathrm{H}$ and $\mathrm{E} x$ 400).

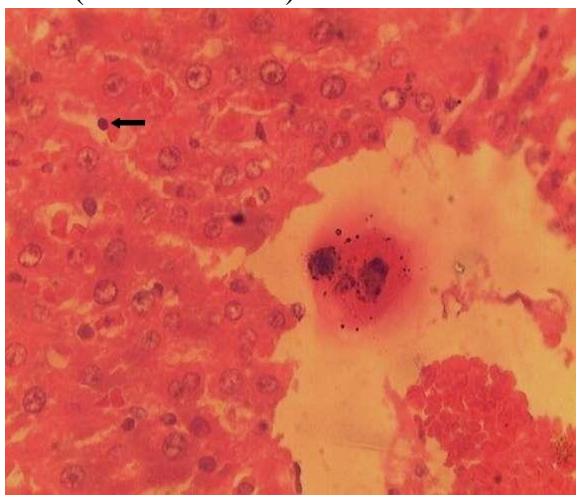

Plate 13: Group CPV1 diabetic rats fed with $5 \mathrm{mls}$ of Cola pachycarpa very rough epicarp variety juice per $\mathrm{kg}$ body weight. The general microscopic architecture of sections of liver tissue from the experimental groups. CPV1 showing dilated sinusoids (arrows) and mild congestion of central vein, CV (Hand E x 400). 


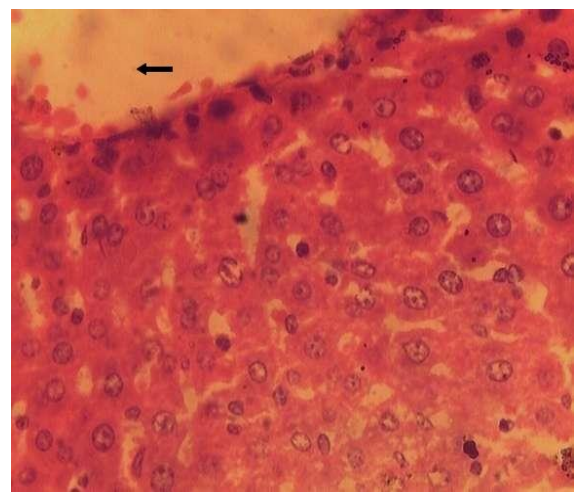

Plate 14: Group CPV2 diabetic rats fed with 10mls Cola pachycarpa very rough epicarp variety juice per kg body weight. Photomicrograph of sections of the liver from experimental rats of group CPV2 which had apparently normal architecture of hepatocytes (arrow) separated by hepatic sinusoids which were not different from group CPV1 ( $\mathrm{H}$ and E x 400).

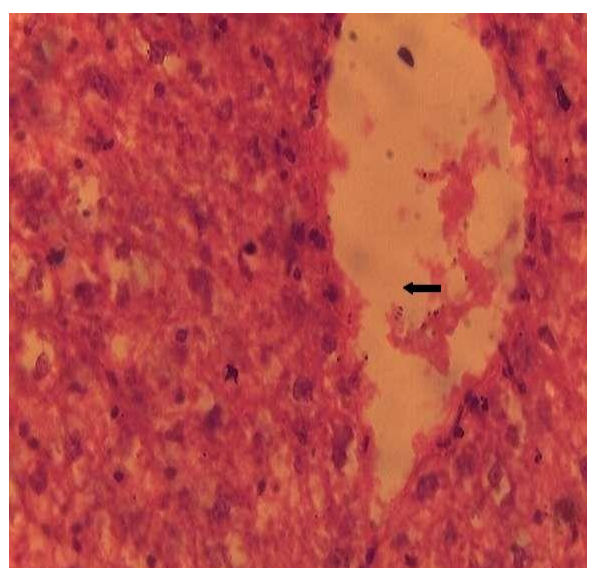

Plate 15: Group CL1 diabetic rats fed with $5 \mathrm{mls}$ Cola lepidota juice per kg body weight.

A Photomicrograph of sections of the liver from experimental rats of group CL1. Note the dilatation of sinusoids in group CL1 (arrow), red pops in central anteroid that shows normal hepatocytes ( $\mathrm{H}$ and E X 400).

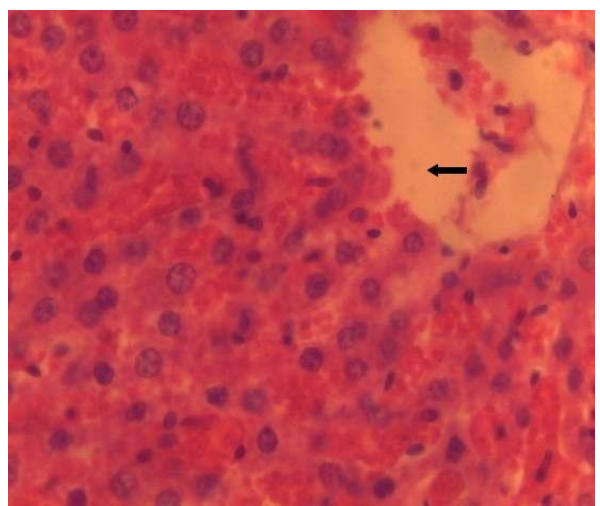

Plate 16: Group CL2 diabetic rats fed 10mls Cola lepidota juice per kg body weight.

A Photomicrograph of sections of the liver from experimental rats of groups CL2 have the normal architecture of hepatocytes (arrow) separated by hepatic sinusoids which were not different among the other groups ( $\mathrm{H}$ and $\mathrm{E} \times \mathrm{400})$. 


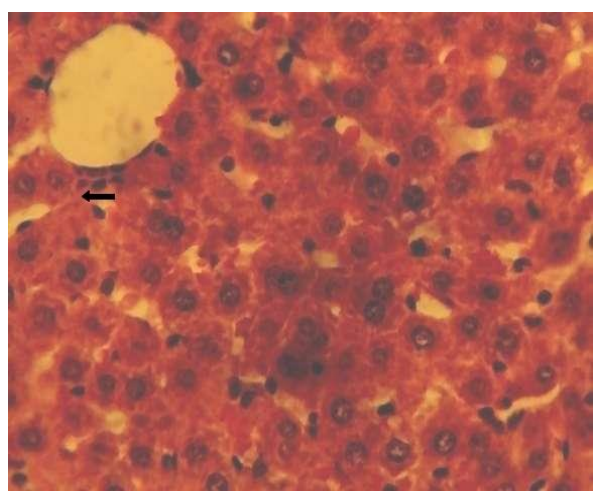

Plate 17: GroupTSD diabetic rats treated with standard drug, glibenclamide. A Photomicrograph of liver sections from the experimental rats of group TSD, treated with standard drug shows normal architecture of liver separated by hepatic sinusoids ( $\mathrm{H}$ and $\mathrm{E} \mathrm{x} 400$ ).

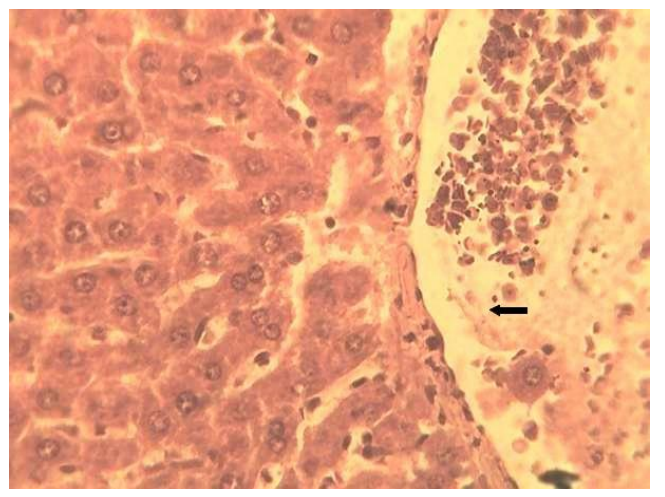

Plate 18: Group NT diabetic rats not treated with drug or juice. A Photomicrograph of sections of the liver from experimental rats of group NT (untreated). Note the apparently abnormal architecture of hepatocytes (arrow) separated by hepatic sinusoids which were different among other groups ( $\mathrm{H}$ and $\mathrm{E} \mathrm{x} \mathrm{400).}$

\section{DISCUSSION}

On induction with diabetes, ALP values increased in all groups of rats. Treatment of the induced diabetic rats with the monkey cola fruit juices significantly $(\mathrm{p}<0.05)$ decreased alkaline phosphatases and aspartate transaminases similar to those treated with standard diabetic drug. Percentage decreases in alkaline phosphatase among the treated groups were between $14.32-29.58 \%$. Only the untreated rats experienced continued increase in alkaline phosphatase which was about $6.79 \%$. Initial increase in the activities of the liver enzymes ALT, AST and ALP could be due to liver injury by poisonous substances, disease, liver cells necrosis and consequent drainage of these enzymes from the liver into the circulatory system (21). According to Thapa and Walia, (22), liver disease is marked with overproduction and leakage of ALP in the blood which is linked with mild and moderate increases in serum ALP. Reduction in markers of liver function in response to treatment with monkey cola fruit juices suggest that they were effective in protecting the liver or repairing liver injuries and reducing the level of the effect of the hepatocellular damage caused by the diabetic disease condition.

Alanine transaminases are enzymes found in large quantites in the liver. High increases in ALT values are associated with hepatitis and specific for hepatocytic necrosis (22). In the present study, ALT values increased $(p<0.05)$ on induction of the experimental rats with diabetes, probably due to liver damage by the disease condition and consequent leakage of this enzyme into the blood (21). Vuksan et al., (23) also reported that alloxan diabetes exerted two-fold increases in serum alanine transaminase, aspartate transaminase and alkaline phosphotase activities. Significant ( $p>0.05)$ reductions were observed in ALT values on treatment of the induced diabetic rats with Cola pachycarpa and Cola lepidota fruit juices (15.27$32.26 \%$ ). The percentage reduction in ALT was lowest in rats which received treatment with standard diabetic drug (11.86\%). These findings may be indicating that the monkey cola fruit juices provided hepatoprotective effects to the diabetic 
animals. The untreated group however suffered increases in serum alanine transaminases $(16.90 \%)$. Some other researchers have demonstrated the potentials of different fruits to improve biochemical indices in diabetic animals $(24,25)$.

In this study, AST values increased on induction with diabetes. Many researchers have reported notable elevations of ALT and AST in animals and humans who are diabetic $(26,27)$. These aspartate transaminases are some other enzymes found in the liver cells. Extra hepatic sources of this enzyme include skeletal, cardiac, muscle, kidney and brain tissues (22). Whenever the liver, cardiac or muscle cells are injured or unhealthy there is release of AST into the blood. An unhealthy or injured liver such as in rats induced with diabetes releases AST into the blood and increases its concentration in the bloodstream. End values of AST on treatment with monkey cola fruit juices decreased by varying percentages (2.53-29.81\%). Only rats induced with diabetes but not treated had significant $(\mathrm{p}<0.05)$ percentage $(14.79 \%)$ rise in AST blood plasma enzymes.

These decreases in the AST levels on treatment with the fruit juices could imply repair of diseased liver, absence of damage to liver, cardiac or other organs and absence of toxic chemical compounds in the monkey cola fruit juices capable of damaging the liver tissues. Antinutrient profile of all the monkey cola fruit juices studied showed that they were all present within safe levels. In addition to these, researchers have reported substantial amounts of flavonoids, alkaloids, phenols and saponins in monkey cola fruits which have contributed to its potential anti-diabetic properties $(28,29)$.

The liver is the main source of the blood serum proteins. The level of total protein in the blood is an indication of its rate of production, breakdown and frequency of distribution (22). There was initial reduction in plasma protein levels of the diabetic rats on induction. Total protein levels increased on treatment in all groups, with highest increases recorded for monkey cola fruit juices (115.04 $42.86 \%$ ). The untreated group recorded significant reduction in total protein $(44.83 \%)$. Decreased protein production with increased muscle breakdown, reduction in production of insulin, and decrease in the production of alkaline phosphatases could precipitate reduction in plasma protein $(30$, 31). Liver and kidney disorders as well as malnutrition could be linked to low levels of total serum protein (32). Irondi et al., (21) suggested that the restoration of protein values towards normal could probably be attributed to the ability of the treatment to help insulin secretion as well as its
DOI: https://dx.doi.org/10.4314/jdan.v12i1.13 action in the diabetic rats. Thapa and Walia, (22) reported that if there is knowledge about liver disease affecting some populations, drug trials may help health personnel to determine the causes of fluctuations effectively.

It was not surprising that in this study, histopathological reports confirmed abnormal hepatocyte structure in only the untreated group of rats. Even though rats treated with monkey cola fruit juices showed an apparently normal hepatocyte structure, those treated with standard drug were significantly different.

The monkey cola fruit juices were effective in significantly reducing blood sugar levels and impacted positively on haematological and biochemical parameters of diabetic rats.

\section{CONCLUSION}

Cola pachycarpa and Cola lepidota fruit juices demonstrated ability to decrease blood glucose level, alkaline phosphatase, aspartate transaminase and effect increase in total protein in diabetic animals similar to the standard diabetic drug. The protective effect of these juices was observed in the histopathological studies, as rats treated with monkey cola fruit juices did not show abnormal hepatocyte structure. These bioactive potentials reviewed are however clearly understudied. In addition to the nutritional values of monkey cola fruits, further research into its anti-diabetic properties should be undertaken. Results from the present study will contribute to nutritional database of bioactive potentials of monkey cola fruit varieties on diabetes- induced rats.

Further research is needed to investigate into the bioactive potentials of Monkey Cola fruit juices. There could be well designed studies using humans to ascertain the biological accessibility, its safety, and outcome over extended periods of use and biologically active substances. Cola pachycarpa and Cola lepidota could be used as herbal medicine alone or alongside prescription drugs for the management of diabetes. There is need to determine the herb-drug interaction of Cola pachycarpa and Cola lepidota with anti-diabetic medication.

Conflict of Interest: There is no conflict of interest in this study.

Authors Contribution: NRI designed the study, conducted the survey, interpreted the data and wrote manuscript draft. CJN Supervised the study and reviewed the manuscript. MAN reviewed the manuscript and updated the references.

\section{REFERENCES}


1. Wilds S, Roglic G, Green A, Sicree R, King H. Global Prevalence of Diabetes: Estimates for 2000 and Projection for 2030. Diabetes Care. 2004; 67(5): 1047-1053.

2. Macedo CS, Capelletti SM, Mercadante MCS, Padovani R, Spadella CT. Role of Metabolic Control on Diabetic Nephropathy. Acta Cirurgica Brasileira. 2002; 17(6): 37-45.

3. Etuk EU. Animal Models for Studying Diabetes Mellitus. Agric and Biol J of North Am. 2010; 1 (2): 130-134.

4. Hjelm KF, Dufour S, Befroy D, Lehrke M, Hendler RE, Shulman GI. Reversal of NonAlcoholic Hepatic Steatosis, Hepatic Insulin Resistance, and Hyperglycemia by Moderate Weight Reduction in Patients with Type 2 Diabetes. Diabetes. 2003; 54: 603-608.

5. World Health Organisation. WHO guidelines on Good Agricultural and Collection Practices (GACP) for Medicinal Plants. World Health Organisation, Geneva; 2003.

6. Functional Foods Fact Sheet. Antioxidants; 2006. Available from www.ific.org/publications/fact sheets/antioxidant.

7. Dragsted LOA, Pedersen A, Hermetter A, Basu S, Hansen M, Haren GR, Kall M, Breinholt V, Castenmiller JM, Stagsted J, Jakobsen J, Skibsted L, Rasmussen SE, Loft S, Sandstrom B. The 6-a-day Study: Effects of Fruits and Vegetables on Markers of Oxidative Stress and Antioxidative Defense in Healthy Nonsmokers. Am J of Clin Nutr. 2004; 79 (6): 1060-1072.

8. Ronald PL. Fruits and Vegetables in the Prevention of Cellular Oxidative Damage. Am J of Clin Nutr. 2003; 78(3), 570S-578S.

9. Dao T, Kasofsky - Flynn J, Rogers A, Rose D, Collins K, Polk M. Taking a Closer look at Phytochemicals. VHL Family Forum 4. Reprinted with Permission from the American Institute for Cancer Research, 1759 R Street, NW, Washington, DC; 1996.

10. Gala DR, Gala S. Improper Food and Habits Fatal to Health: Juice-Diet for Perfect Health. India: Navneet Publications Ltd; 2001:5-10.

11. Soetan KO. Pharmacological and other Beneficial Effects of Anti-Nutritional Factors in Plants - A Review. Afr J of Biotech. 2008; 7(25): 4713- 4712.

12. Okafor JC. Horticulturally Promising Indigenous Wild Plant Species of the Nigerian Forest Zone Acts. Horticulture. 1983;123: 165177.

13. Sofowora EA. Isolation and Characterization of an Anti-Sickling Agent from Fagara zanthoxyloides. J of Natural Prod (Lloydia).1975; 38: 169-171.

14. Okudu HO, Asumugha VU. Nutrient Potentials and Phytochemical composition of Two
DOI: https://dx.doi.org/10.4314/jdan.v12i1.13

Varieties of Monkey Kola (Cola pachycarpa, Cola lepidota) Seed flour. CPQ Nutrition. 2018; 1(1): 01-10.

15. Sofowora A. Screening Plants for Bioactive Agents. In: Medicinal Plants and Traditional Medical in Africa. Ibadan, Nigeria: Spectrum Books Ltd. 1993:134-156.

16. Tijjani H, Luka CD. Effects of Afromomum melegueta, Zingiber officinale and Piper nigrumon on some biochemical and haematological Parameters in rats fed with high lipid diet. Intern $\mathbf{J}$ of Pure and Appl Biosci. 2013;1(3):61-67

17. Lenka J, Luka CD, Nansah LS. The effect of Aqueous Extract of Buchholzia coriacea Seeds on Some Biochemical Parameters in Normal and Alloxan-Induced Diabetic Rats. Intern $\mathbf{J}$ of Biochem Res and Rev. 2016; 11(1): 1-10.

18. Reitman S, Frankel S. A Colorimetric Method for The Determination of Serum Glutamic Oxaloacetic And Glutamic Pyruvic Transaminases. Am J of Clin Path. 1957; 28:56.

19. Babson AL, Greeley SJ, Coleman CM, Philips GE. Blood biochemical abnormalities associated with sub-chronic contamination of drinking water with sub lethal concentrations of inorganic fertilizer; 1966. Available from https//www.researchgate.net.

20. Tietz NW. Clinical guide to Laboratory tests (ELISA). Scientific Research Publishing. W.B. Saunders Co., Philadelphia; 1995.

21. Irondi AE, Oboh $\mathrm{G}$, Akindahunsi AA. Antidiabetic effects of Mangifera indica Kernel Flour-supplemented diet in streptozocininduced type 2 diabetes in rats. Food Sci \& Nutr. 2016; 4(6):828-839.

22. Thapa BR, Walia A. Liver Function Tests and their Interpretation. Ind $\mathrm{J}$ of Paed. 2007; 74:663-671.

23. Vuksan V, Sievenpiper J, Koo VYY,Francis T, Beljan-Zdravkovic U, Xu U. Vidgen E. American Ginseng Panax Quinquefolius L Reduces Postprandial Glycemia in Nondiabetic Subjects And Subjects With Type 2 Diabetes Mellitus. Arch of Internal Med. 2000; 160:1009-1013.

24. Nerurkar VP, Hwang WP, Saksa E. AntiDiabetic Potential of Noni: The Yin and the Yang. Molecules.2015; 20:17684-17719.

25. Devalaraja S, Jain S, Yadav H. Exotic Fruits as Therapeutic Complements for Diabetes, Obesity and Metabolic Syndrome. Food Research International, 2011; 44 (7): 18561865.

26. Awadallah R, Dessoukey EA. Serum Enzymes Changes In Experimental Diabetes Before And After Treatment With Some Hypoglycaemic Drugs. Z Ernahringswiss. 1977; 16: 235-240. 
27. Henry RJ, Chiamori N, Golub OJ, Berkman S. Revised Spectrophotometric Methods For the Determination Of AST, ALT and LDH. Am J of Clin Pathol. 1960;34: 381-398.

28. Essien EE, Peter NS, Akpan MS. Chemical Composition and Antioxidant Property of Two Species of Monkey Kola (Cola rostrata and Cola lepidota K.Schum) Extracts. Euro J of Med Plants. 2015; 7(1):31-37.

29. Udousoro II, Essien EE. Amino Acids, Vitamins and Other Nutritional and Antinutritional Components of Cola lepidota (Monkey Kola). Am Assoc for Sci \& Techn. 2017; 4 (3):2375-3803.
DOI: https://dx.doi.org/10.4314/jdan.v12i1.13

30. Gray SP, Cooper ME. Diabetic nephropathy in 2010: alleviating the burden of diabetic nephropathy. Nature Rev Nephrol .2011; 7:7173.

31. Murugan P, Pari L. Influence of tetrahydro curcumin on hepatic and renal functional markers and protein levels in experimental type 2 diabetic rats. Basic \& Clinical Pharmacol \& Toxicol. 2007; 101: 241-245

32. Burtis CA, Ashwood ER, Bruns DE. Teitz Textbook of Clinical Chemistry and Molecular Diagnostics. St. Louis: Elsevier Inc; 2006. 